College Hospital and also at the Royal Eye Hospital; it was mainly through the advice and influence of Professor McHardy that Cargill subsequently decided to take up the study and practice of ophthalmology. On November 1, 1890, Cargill was appointed house surgeon to Professor Sir Joseph Lister (later Lord Lister) at King's College Hospital. In 1892 he was made F.R.C.S. and in 1893 he became house surgeon and surgical registrar at the Royal Eye Hospital, but in 1894 he returned to King's College Hospital where he had been appointed Sambrooke Surgical Registrar. In 1896 he returned to the Royal Eye Hospital as assistant surgeon, and 3 years later was appointed assistant ophthalmic surgeon at King's College Hospital and ophthalmic surgeon to the Dreadnought Seamen's Hospital, Greenwich.

During the South African War he served as ophthalmic surgeon to the Imperial Yeomanry Hospital in South Africa and was awarded a Medal and Clasps; on his return to England he resumed his duties at King's College Hospital and at the Royal Eye Hospital. At the outbreak of the 1914-1918 war Cargill was appointed honorary consultant for diseases of the eye in the military hospitals in London, and he took charge of the ophthalmic beds at the Fourth London General Hospital, located at Denmark Hill; he was awarded the Red Cross War Medal.

Vernon Cargill served on the Councils of the Ophthalmological Society of the United Kingdom and the Oxford Ophthalmological Congress, and was an examiner for the diploma in ophthalmology at Oxford. He was a fellow of the Royal Society of Medicine, and the Medical Society of London, and King's College, London.

In 1930 he took part in the annual meeting of the "Pacific Coast" Oto-ophthalmological Society at Victoria, British Columbia, and represented King's College Hospital Medical School at the formal opening of the Banting Institute, University of Toronto.

In 1931 he retired from the active staff of King's College Hospital; he was then appointed emeritus lecturer on ophthalmology in the medical school and honorary consulting ophthalmic surgeon to the hospital. He was appointed consulting surgeon to the Royal Eye Hospital, and elected chairman of the council, a post which he held until 1948. $\mathrm{He}$ also became consulting ophthalmic surgeon to the Dreadnought Seamen's Hospital, Greenwich.

He had been a member of the court of the Society of Apothecaries of London and was master of the society in 1939-1940. He had also been vice-president and treasurer of the Board of Registration of Medical Auxiliaries.

Cargill's long life extended over the Victorian and Edwardian periods and the turbulent years of two world wars. He played his part in the transformation of ophthalmology from a minor branch of general surgery into an independent and significant specialty.

In the early years of his association with the Royal Eye Hospital, his wide experience and technical skill coupled with a keen and searching mind made him one of the most outstanding members of the honorary staff, and more recently was a valuable elder statesman, being chairman of the council for 17 years.

In 1897 Vernon Cargill married Miss Emma Sherwood, the only daughter of the late William Sherwood; she died in 1951. There are three daughters of the marriage.

\title{
William John Crozier
}

Professor William J. Crozier, who occupied with great distinction the Chair of General Physiology at Harvard University, died on November 2, 1955. Professor Crozier was a research worker of great authority on visual problems, particularly those associated with the fundamental processes by which light stimulates vision. He was well known in Great Britain, and particularly at the Institute of Ophthalmology in London. 